\title{
Effects of Gui Zhu Yi Kun formula on the P53/AMPK pathway of autophagy in granulosa cells of rats with polycystic ovary syndrome
}

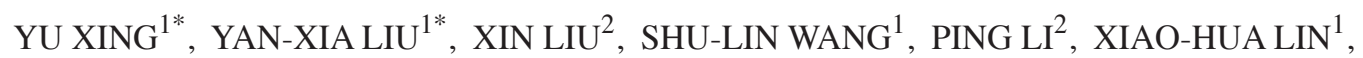 \\ CONG-LU SUI ${ }^{1}$, CAI XU ${ }^{1}$, BING QI $^{1}$ and QING TONG ${ }^{1}$ \\ ${ }^{1}$ Department of Gynecology, Dongfang Hospital, Beijing University of Chinese Medicine, Beijing 100078; \\ ${ }^{2}$ Department of Pathophysiology, Beijing Institute of Traditional Chinese Medicine, Beijing 100010, P.R. China
}

Received November 12, 2015; Accepted December 9, 2016

DOI: $10.3892 /$ etm.2017.4384

\begin{abstract}
The aim of the present study was to investigate the molecular mechanism associated with the traditional Chinese medicine formula Gui Zhu Yi Kun formula (GZYKF), in the treatment of polycystic ovary syndrome (PCOS). In this study, granulosa cells (GCs) of rats with PCOS were cultured and treated with testosterone propionate (TP) alone or with serum from rats treated with different doses of GZYKF. The effect of TP on cell growth was assayed using the MTT method. Expression levels of Beclin-1, light chain (LC)3, mechanistic target of rapamycin (mTOR), tumor suppressor p53 (p53), adenosine monophosphate-activated protein kinase (AMPK), sestrin 2 and tuberous sclerosis protein $1 / 2$ were evaluated using quantitative polymerase chain reaction and western blotting. It was demonstrated that TP increased the expression of Beclin-1 and LC3, whereas GZYKF significantly decreased the TP-induced expression of Beclin-1 $(\mathrm{P}<0.01)$. Additionally, GCs treated with GZYKF exhibited significant increases in mTOR, phosphorylated mTOR and AMPK $\alpha$ expression levels, and significant reductions in p53 and sestrin 2 expression levels were observed. In conclusion, the findings of the present study suggest that a reduction in ovarian GCs in rats with PCOS may be associated with GC autophagy. Furthermore, the effects of GZYKF in mediating the p53/AMPK pathway may inhibit GC autophagy, which suggests a possible novel mechanism underlying the treatment of PCOS with GZYKF.
\end{abstract}

Correspondence to: Dr Qing Tong, Department of Gynecology, Dongfang Hospital, Beijing, University of Chinese Medicine, 6 Fangxingyuan Road, Fengtai, Beijing 100078, P.R. China E-mail: tammytongq@126.com

\section{${ }^{*}$ Contributed equally}

Key words: autophagic cell death, Chinese herbal medicine, mechanistic target of rapamycin, polycystic ovary syndrome

\section{Introduction}

Polycystic ovary syndrome (PCOS) is one of the most prevalent endocrine disorders in gynecology (1). PCOS may lead to various reproductive endocrine disorders and long-term health complications, and is therefore a potential threat to the health of women. Despite its health impacts, the pathophysiology of PCOS remains to be elucidated. In a previous study, it was reported that treatment of PCOS using Gui Zhu Yi Kun formula (GZYKF) was effective (2). However, the underlying mechanism associated with the therapeutic effects GZYKF also remains to be elucidated.

Autophagy is a cellular process which is known to participate in the pathological progression of various diseases. Autophagy is able to induce cell death that is distinct from that initiated by apoptosis (3). In the heart, excessive autophagy may be induced by severe stress, which results in cell death (4). Autophagic cell death may also occur if unfavorable metabolic conditions are established during cancer progression (5) and the inhibition of autophagy may be a potential avenue for anticancer therapy (6). Therefore, it is important to elucidate the molecular mechanisms associated with autophagy-induced cell death.

In the last decade, autophagy signaling pathways and major protein regulators have been identified. The rat microtubule-associated protein 1 light chain (LC)3, is associated with autophagosome membranes following processing (7). Beclin-1 has also been demonstrated to serve a critical role in autophagosome formation (8). Furthermore, previous studies have identified tumor suppressor p53 (p53) as a dual modulator of autophagy in regulating cell death and survival $(9,10)$. At low energy levels, adenosine monophosphate-activated protein kinase (AMPK), which is activated by $\mathrm{p} 53$, is able to activate tuberous sclerosis complex (TSC) 2 and thus inhibit mammalian target of rapamycin (mTOR) activity and ultimately increase autophagy (11).

The authors of the present study have previously demonstrtated that the autophagy rate of granulosa cells (GCs) in rats with PCOS is significantly increased as compared with normal control rats, and that the decrease of ovarian GCs in rats with PCOS may be associated with autophagic cell death (12). 
Therefore, in the present study, GCs of rats with PCOS were used as an experimental model and testosterone propionate (TP) was used to induce autophagy. The aim of the present study was to investigate the molecular mechanism associated with the traditional Chinese medicine GZYKF in the treatment of PCOS.

\section{Materials and methods}

Antibodies and reagents. Dulbecco's modified Eagle's medium/nutrient mixture F-12 (DMEM/F12) and fetal bovine serum (FBS) were obtained from Gibco (Thermo Fisher Scientific, Inc., Waltham, MA, USA). Penicillin, streptomycin, and dimethylsulfoxide were purchased from Sigma-Aldrich (Merck Millipore, Darmstadt, Germany). Anti-p53 (cat. no. TDY075), -GAPDH (cat. no. REK0005) and - $\beta$-actin antibodies (cat. no. TDY041) were obtained from Beijing TDY Biotech Co., Ltd., (Beijing, China). Anti-follicle-stimulating hormone receptor (FSHR) antibody (cat. no. orb213952) was purchased from Biorbyt (Cambridge UK). Anti-LC3 (cat. no. 4108), -Beclin-1 (cat. no. 3495), -phosphorylated (p-)mTOR (cat. no. 5536), -mTOR (cat. no. 2983) and -AMPKa (cat. no. 2532) antibodies, and bovine serum albumin (cat. no. 9998) were purchased from Cell Signaling Technology, Inc., (Danvers, MA, USA). Anti-sestrin antibody (cat. no. 10795-1) was purchased from ProteinTech Group, Inc., (Chicago, IL, USA). GZYKF was obtained from Dongfang Hospital of Beijing University of Chinese Medicine (Beijing, China).

Cell culture. A total of 50 immature (23-25 days old) female Sprague-Dawley rats, with a weight of $60 \pm 10 \mathrm{~g}$, were obtained from Vital River Laboratory Animal Technology Co., Ltd. (Beijing, China; certificate no: SCXK 2006-0008). GCs were obtained from these Sprague-Dawley rats, to which 40 IU pregnant mare serum gonadotropin (cat. no. HOR-272; Prospec-Tany TechnoGene, Ltd., East Brunswick, NJ, USA) had been subcutaneously administered. All experimental procedures were conducted in accordance with the guidelines of National Institutes of Health for the Care and Use of Laboratory Animals. Rats were raised under a 12-h light/dark cycle, at $22 \pm 2^{\circ} \mathrm{C}$ and with humidity of $35-45 \%$ with ad libitum access to food and water. All rats were sacrificed via cervical dislocation and GCs were subsequently isolated using standard protocols (13), and 10 million cells were seeded in a $25-\mathrm{cm}^{2}$ culture flask with DMEM/F12 culture medium containing $1 \%$ penicillin/streptomycin, and $10 \% \mathrm{FBS}$, and incubated for 5 days in an atmosphere containing $5 \% \mathrm{CO}_{2}$ at $37^{\circ} \mathrm{C}$. Following $24 \mathrm{~h}$ of incubation, non-adherent cells were removed and culture medium was changed every two days.

Immunohistochemistry. GCs were characterized by immunohistochemical staining to detect the expression of FSHR, which is a specific GC marker (14). Stably transfected GCs were plated on glass slides prior to fixation in $4 \%$ paraformaldehyde. Endogenous peroxidases were blocked by incubation in $3 \% \mathrm{H}_{2} \mathrm{O}_{2}$ at room temperature for $10 \mathrm{~min}$ and $0.1 \%$ Triton $\mathrm{X}-100$ was added for $10 \mathrm{~min}$ at room temperature. Following washing with PBS three times (3 min each), nonspecific binding was blocked by incubation in PBS containing 5\% bovine serum albumin. Anti-FSHR antibody (1:100) was added at $4^{\circ} \mathrm{C}$ overnight and non-immune IgG (1:100; cat. no. NIR-IG; Affinity Biologicals, Inc., Ancaster, Canada) was used as a negative control. Following washing with PBS three times (3 min each), horseradish peroxidase-conjugated goat anti-rabbit IgG (1:100; cat. no. S001; Beijing TDY Biotech Co., Ltd.) was added in the dark at $37^{\circ} \mathrm{C}$ for $45 \mathrm{~min}$. Antigenic sites were localized using a 3,3'-diaminobenzidine kit (cat. no. ZLI-9018; ZSGB-BIO, Beijing, China). Images were captured on a light microscope.

Cell cytotoxicity assay. The effect of testosterone propionate (TP) on cell growth was assayed using the MTT method (15). Cells were cultured in 96 -well plates $\left(10^{4}\right.$ cells/well) at $37^{\circ} \mathrm{C}$ and stimulated with different concentrations of TP $\left(10^{-4}, 10^{-5}\right.$, $10^{-6}, 10^{-7}, 10^{-8}$ and $0 \mathrm{~mol} / \mathrm{l}$ ) in DMEM/F12 medium. Following 24, 48 and $72 \mathrm{~h}$ of stimulation with TP, MTT was added to each well (final concentration, $0.5 \mathrm{mg} / \mathrm{ml}$ ) and incubated for a further $4 \mathrm{~h}$. The viable cell number was directly proportional to the production of formazan following solubilization with $10 \%$ sodium dodecyl sulfate. Color intensity was measured at $490 \mathrm{~nm}$. Each condition was performed in triplicate, and data were obtained from at least three separate experiments.

Preparation of GZYKF-containing rat serum. Water soluble extracts of GZYKF were prepared as follows: GZYKF included $20 \mathrm{~g}$ Tu Si-zi (Semen Cuscutae), $15 \mathrm{~g}$ Bai zhu (Rhizoma Atractylodis Macrocephalae), 15 g Dang gui (Angelica sinensis), $12 \mathrm{~g}$ Sha Shen (Adenophora tetraphylla), 15 g Che Qian-zi (Plantago asiatica), 12 g Qian Cao (Rubia cordifolia) and $10 \mathrm{~g}$ Si Gua-luo (Luffa cylindrica) were used. Herbs were initially subjected to soaking for $1 \mathrm{~h}$ in water at room temperature, followed by $1 \mathrm{~h}$ of decoction at $100^{\circ} \mathrm{C}$. Extracts harvested from the decoction were vacuum dried, and water soluble extracts of GZYKF were dissolved in double distilled water $\left(\mathrm{ddH}_{2} \mathrm{O}\right)$ at $1.8 \mathrm{~g} / \mathrm{ml}$.

A total of 40 6-week-old female Sprague-Dawley rats (weight, 200 \pm 10 g; Vital River Laboratory Animal Technology Co., Ltd.) were randomly divided into four groups ( $\mathrm{n}=10$ each), and housed under the same conditions as the rats used for GC culture. Rats in low, medium and high dose GZYKF groups were administered GZYKF via gavage in doses of 5, 10 and $20 \mathrm{~g} / \mathrm{kg}$ daily, respectively, whereas rats from the vehicle control group were administered volume-matched $\mathrm{ddH}_{2} \mathrm{O}$ via gavage. Daily dosages of GZYKF were divided into equal shares and administered to rats in the low, medium and high dose groups once, twice or thrice per day for 4 days, respectively. On day 5 , following $12 \mathrm{~h}$ of fasting, rats were anesthetized by intraperitoneal injection of $0.4 \%$ pentobarbital $(10 \mathrm{ml} / \mathrm{kg}$; cat. no. 1507002; Sigma-Aldrich; Merck MIllipore) and rat aortic blood was harvested. The majority of rats succumbed to mortality due to blood loss; however, when this was not the case, rats were sacrificed via cervical dislocation. Blood serum was obtained via centrifugation $(1,509 \times \mathrm{g})$ of blood at $4^{\circ} \mathrm{C}$ for $20 \mathrm{~min}$. Serum was subsequently heat-inactivated at $56^{\circ} \mathrm{C}$ for $30 \mathrm{~min}$. Finally, the GZYKF-containing serum was sterilized via filtration through $0.22-\mu \mathrm{m}$ cellulose ester membranes.

Treatment. GCs were divided into six groups, and each group contained $\sim 3 \times 10^{5}$ cells. Groups 1 (control group) and 6 were treated with $15 \%$ FBS. Groups 2 to 6 were treated with 
Table I. Gene-specific primer pairs.

\begin{tabular}{|c|c|c|}
\hline Gene & Primer sequence (5' to $3^{\prime}$ ) & Amplicon (bp) \\
\hline Beclin-1 & $\begin{array}{l}\text { F: CAGTGTTGTTGCTCCATGCT } \\
\text { R: TGCACACAGTCCAGAAAAGC }\end{array}$ & 202 \\
\hline LC3 & $\begin{array}{l}\text { F: TTCTTCCTCCTGGTGAATGG } \\
\text { R: GTGGGTGCCTACGTTCTGAT }\end{array}$ & 253 \\
\hline GAPDH & $\begin{array}{l}\text { F: TGGAGTCTACTGGCGTCTT } \\
\text { R: TGTCATATTTCTCGTGGTTCA }\end{array}$ & 138 \\
\hline p53 & $\begin{array}{l}\text { F: CCTCACCATCATCACACTGGAAGAC } \\
\text { R: GTCTCTCCCAGGACAGGCACAAAC }\end{array}$ & 91 \\
\hline AMPK & $\begin{array}{l}\text { F: ACAGGAGAATAATGAATGAAGCCAA } \\
\text { R: ATGCCATTTTGCTTTCCTTACACCT }\end{array}$ & 203 \\
\hline TSC1 & $\begin{array}{l}\text { F: TTGACTGTTGTAATGACGGGTGCTC } \\
\text { R: TCCACCACCTCTGCTTCCACTACT }\end{array}$ & 131 \\
\hline TSC2 & $\begin{array}{l}\text { F: ACGAGTCAAACAAGCCAATCCTG } \\
\text { R: TTGTGGGTGTCGTATGATGGGAT }\end{array}$ & 97 \\
\hline mTOR & $\begin{array}{l}\text { F: AAAACCTCAGCATCCAGAGATACGC } \\
\text { R: CATCAGAGTCAAGTGGTCATAGTCCG }\end{array}$ & 191 \\
\hline sestrin2 & $\begin{array}{l}\text { F: TACAATACCATCGCCATGCACAGT } \\
\text { R: GGTTCACCTCCCCATAATCATAGTCA }\end{array}$ & 121 \\
\hline$\beta$-actin & $\begin{array}{l}\text { F: ACTTAGTTGCGTTACACCCTT } \\
\text { R: GTCACCTTCACCGTTCCA }\end{array}$ & 156 \\
\hline
\end{tabular}

F, forward; R, reverse; LC, light chain; p53, tumor suppressor p53; AMPK, adenosine monophosphate-activated protein kinase; TSC, tuberous sclerosis protein; mtor, mechanistic target of rapamycin.

$10^{-5} \mathrm{~mol} / \mathrm{l}$ TP for $24 \mathrm{~h}$. Groups 2,3 and 4 were subsequently treated for $72 \mathrm{~h}$ with high-dose, medium-dose and low-dose GZYKF-containing serum $(2 \% \mathrm{FBS}+13 \%$ rat serum containing GZYKF), respectively. Group 5 was treated with $2 \% \mathrm{FBS}+13 \%$ rat serum without GZYKF.

Reverse transcription-quantitative polymerase chain reaction (RT-qPCR). GC total RNA was extracted using TRIzol reagent (Beijing CWBio Co., Ltd., Beijing, China). DNase I kit (cat. no. CW2090; CWBio Co., Ltd.) was used to remove genomic DNA. Total RNA was reverse-transcribed into cDNA, using a HiFi-MMLV cDNA kit (cat. no. CW0744; CWBio Co., Ltd.) according to the manufacturer's protocol. qPCR was performed using the Ultra SYBR Mixture (cat. no. CW0956; CWBio Co., Ltd.) and GoldStar Taq DNA Polymerase according to the manufacturer's protocol. Each PCR reaction was performed in a $20 \mu \mathrm{l}$ system including the following: $10 \mu \mathrm{l} 2 \mathrm{X}$ Ultra SYBR Mixture, $0.4 \mu \mathrm{l}$ forward primer $(10 \mu \mathrm{M}), 0.4 \mu \mathrm{l}$ reverse primer $(10 \mu \mathrm{M}), 2 \mu \mathrm{l}$ cDNA, and $7.2 \mu \mathrm{l}$ ultrapure water. Gene-specific primer pairs are presented in Table I. PCR was performed at $95^{\circ} \mathrm{C}$ for $2 \mathrm{~min}$, followed by 35 cycles of $95^{\circ} \mathrm{C}$ for $15 \mathrm{sec}$, $55^{\circ} \mathrm{C}$ for $15 \mathrm{sec}$, and $68^{\circ} \mathrm{C}$ for $20 \mathrm{sec}$. GAPDH was quantified as an internal control. Results were analyzed using the $2^{-\Delta \Delta \mathrm{Cq}}$ method (16). Three independent experiments were performed.

Western blot analysis. From each group, $\sim 3 \times 10^{6}$ cells were harvested, and a protein extraction kit (cat. no. WB0001;
Beijing TDY Biotech Co., Ltd.) was used on ice for $10 \mathrm{~min}$, followed by centrifugation at $18,000 \times \mathrm{g}$ at $4^{\circ} \mathrm{C}$ for $20 \mathrm{~min}$. The supernatants were collected, and protein concentration was determined using a BCA assay kit (cat. no. WB0028; Beijing TDY Biotech Co., Ltd.). Equal amounts of protein $(10 \mu \mathrm{g})$ were separated by 5 (stacking gel) or $10-15 \%$ (separation gel) SDS-PAGE and transferred onto a PVDF membrane. The blot was subsequently incubated with $5 \%$ non-fat milk in PBS at room temperature for $1 \mathrm{~h}$ to block non-specific binding, and membranes were incubated with the following primary antibodies: p53 monoclonal antibody $(1: 1,000)$, p-mTOR monoclonal antibody $(1: 1,000)$, mTOR monoclonal antibody (1:1,000), AMPK $\alpha$ antibody (1:4,000), LC3 monoclonal antibody (1:2,000), Beclin-1 monoclonal antibody $(1: 2,000)$, sestrin antibody $(1: 2,000), \beta$-actin monoclonal antibody $(1: 5,000)$ and GAPDH monoclonal antibody (1:20,000) overnight at $4^{\circ} \mathrm{C}$, and an appropriate peroxidase-conjugated secondary antibody (1:10,000; goat anti-rabbit IgG, cat. no. 111035003; or goat anti-mouse IgG, cat. no. 115035003; both Jackson ImmunoResearch Laboratories, Inc., West Grove, PA, USA) was added for $1 \mathrm{~h}$. Following the final washing with TBST, signals were developed via an electrochemiluminescence detection system (cat. no. WBKLS0500; Merck Millipore), and relative photographic density was quantitated via gel documentation and analysis using the Image-Pro Plus 6.0 software (Media Cybernetics, Inc., Rockville, MD, USA). Three independent experiments were performed. 


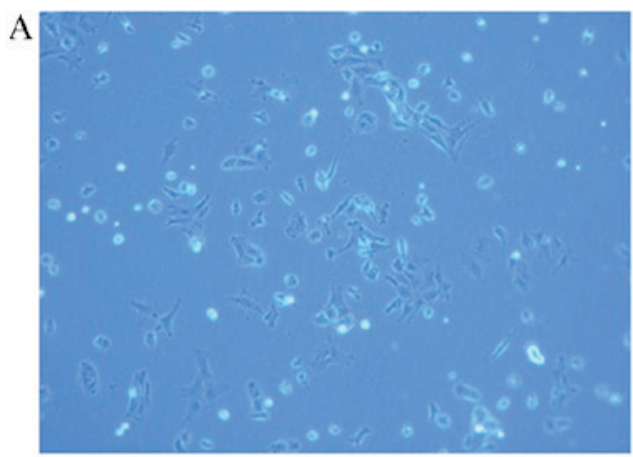

$1 \mathrm{~d}(\times 10)$

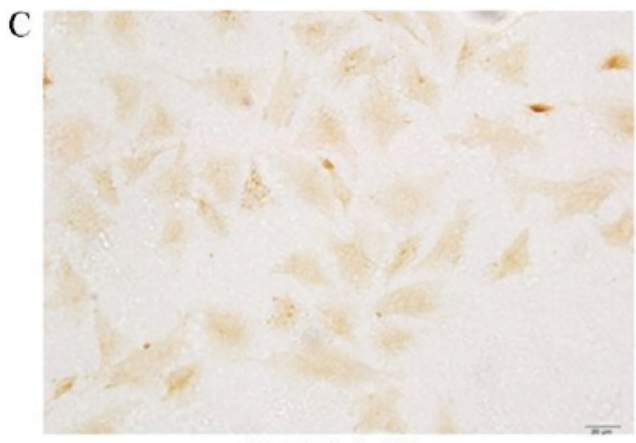

Control $(\times 40)$

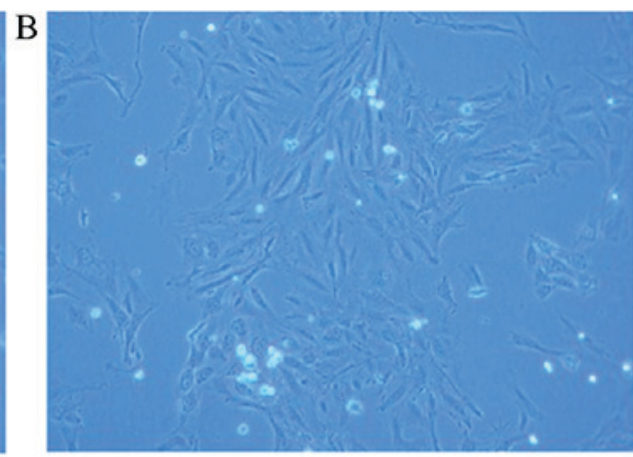

$3 d(\times 10)$

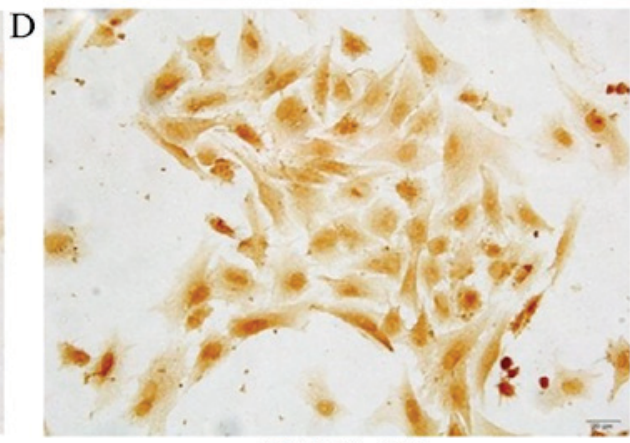

$\operatorname{FSHR}(\times 40)$

Figure 1. GC culture and characterization. Morphology (phase-contrast images; magnification, x10) of rat ovary GCs in culture at (A) $1 \mathrm{~d}$ and (B) $3 \mathrm{~d}$ time points. Images of (C) control and (D) anti-FSHR antibody stained with cultured GCs. GCs with FSHR were stained brown. GC, granulosa cell; d, day(s); FSHR, follicle-stimulating hormone receptor.

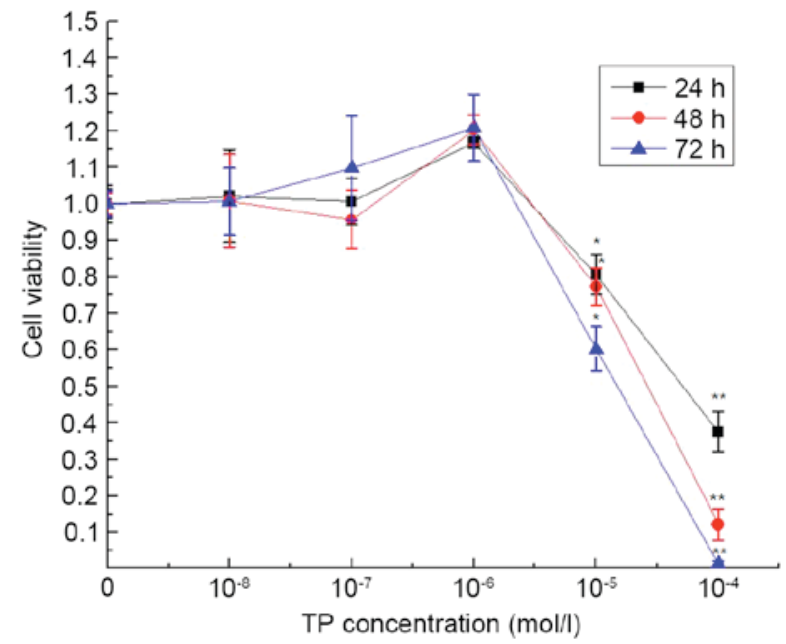

Figure 2. Cell cytotoxicity assay. The concentrations of TP used were $10^{-10}$, $10^{-8}, 10^{-6}, 10^{-4}$ and $10^{-2} \mathrm{~mol} / \mathrm{l}$. When concentration of TP was $>10^{-6} \mathrm{~mol} / 1$, cell growth was inhibited in a time- and dose-dependent manner. The mean inhibitory rate following treatment with $10^{-5} \mathrm{~mol} / 1 \mathrm{TP}$ for $24 \mathrm{~h}$ was $20 \%$, and cell viability was significantly decreased compared with the control group ( $\mathrm{t}=3.68 ; \mathrm{P}=0.021) .{ }^{*} \mathrm{P}<0.05,{ }^{* *} \mathrm{P}<0.01$ vs. control group. TP, testosterone propionate.

Statistical analysis. Values are presented as the mean \pm standard deviation. Statistical significances of differences were analyzed via $t$-test for two groups, or one-way analysis of variance test for three or more groups. Analyses were performed using SPSS 22.0 software (IBM SPSS, Armonk, NY, USA). $\mathrm{P}<0.05$ was considered to indicate a statistically significant difference.

\section{Results}

GC isolation and characterization. Cultured cells adhered gradually and displayed spindle-shaped morphology (Fig. 1A and B). Cells were identified as GCs by the presence of FSHR-stained antibodies (Fig. $1 \mathrm{C}$ and D).

Cell cytotoxic effects of TP on GCs. To determine the cytotoxicity of TP, GCs were treated with different concentrations of TP $\left(10^{-4}, 10^{-5}, 10^{-6}, 10^{-7}\right.$ or $\left.10^{-8} \mathrm{~mol} / \mathrm{l}\right)$ for 24,48 and $72 \mathrm{~h}$. Results from an MTT assay of cell viability indicated that, when the concentration of TP was $>10^{-6} \mathrm{~mol} / \mathrm{l}$, TP was able to inhibit the growth of GCs in a time- and dose-dependent manner (Fig. 2). The minimum TP stimulation time was $24 \mathrm{~h}$. As the number of GCs is lower than normal in the ovaries of rats with PCOS, the optimal concentration of TP was set at $10^{-5} \mathrm{~mol} / \mathrm{l}$. Cell viability was significantly decreased following $24 \mathrm{~h}$ of treatment with $10^{-5} \mathrm{~mol} / \mathrm{l} \mathrm{TP}$, compared with the control group $(\mathrm{t}=3.68 ; \mathrm{P}=0.021)$.

GZYKF decreases the autophagy rate of GCs. Beclin-1 and LC3 mRNA and protein levels in cultured GCs were quantified via RT-qPCR and western blotting, respectively, to evaluate the correlation between the reduction of GCs in the ovary with PCOS and autophagy, and the effect of GZYKF on the autophagy rate of GCs. LC3 is a typically-used marker for autophagy activation due to its critical role as a structural protein in autophagosome formation (17). Beclin-1 was analyzed as a marker of autophagy in the participation and regulation of autophagosomes. The mRNA expression of Beclin-1 and LC3 was demonstrated to be significantly 
A

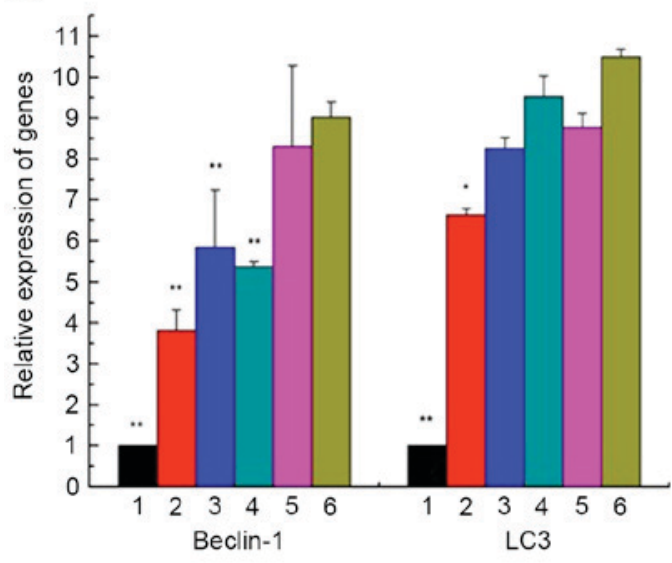

B

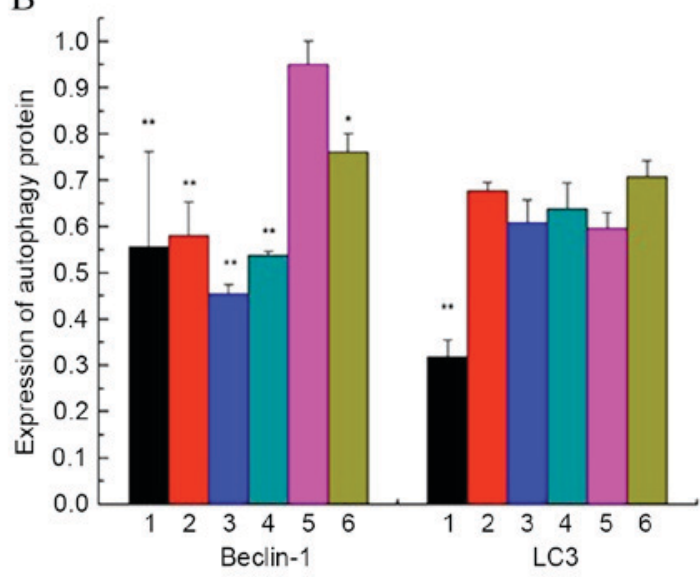

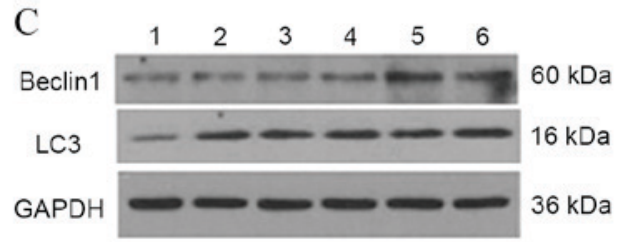

Figure 3. (A) mRNA expression of autophagy-related genes Beclin-1 and LC3, detected by reverse transcription-quantitative polymerase chain reaction, were higher in groups 5 compared with group 1. (B and C) Protein expression of Beclin-1 and LC3 were detected by western blotting. The results indicated that expression levels of autophagy-related proteins Beclin-1 and LC3 were significantly higher in groups 5 than in group 1. GZYKF decreased the protein expression levels of Beclin-1, and high-dose GZYKF decreased the protein expression levels of LC3. Data are presented as mean \pm standard error of the mean of three independent experiments. ${ }^{*} \mathrm{P}<0.05,{ }^{* *} \mathrm{P}<0.01$ vs. group 5. LC, light chain; TP, testosterone propionate; GZYKF, Gui Zhu Yi Kun formula; group 1, control; group 2, treated with TP and high-dose GZYKF-containing serum; group 3, treated with TP and medium-dose GZYKF-containing serum; group 4, treated with TP and low-dose GZYKF-containing serum; group 5, treated with TP and serum without GZYKF; group 6, treated with TP.

A

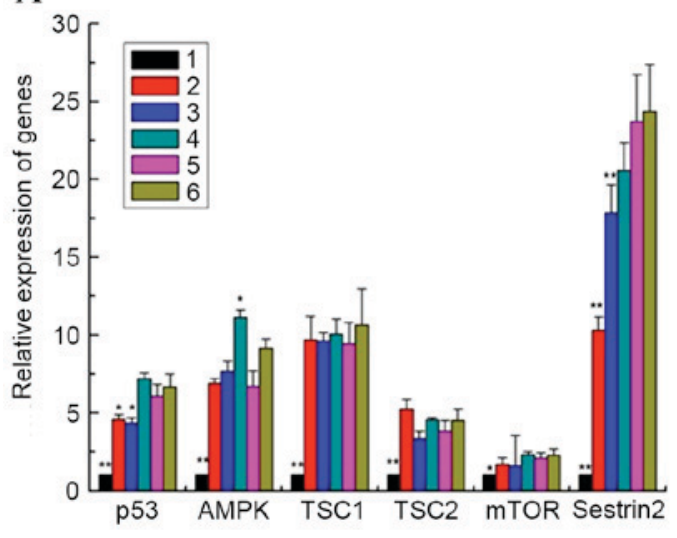

$\mathrm{C}$

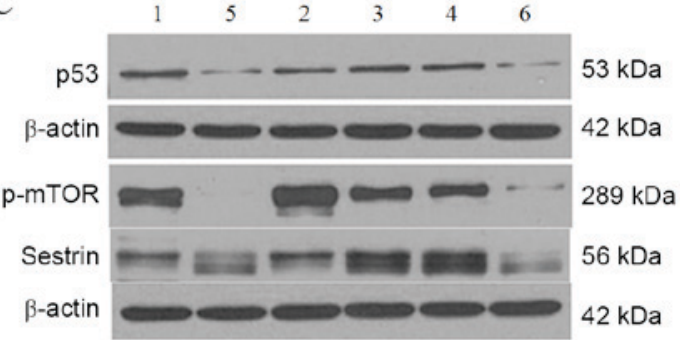

B

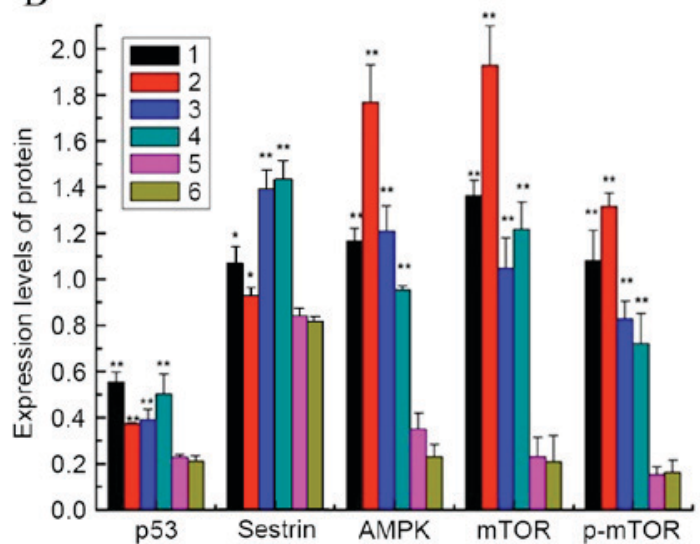

$\mathrm{D}$

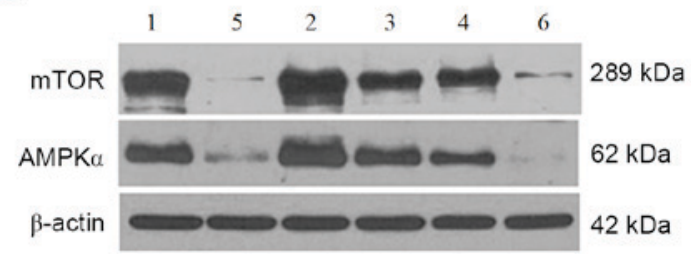

Figure 4. (A) mRNA expression of p53/AMPK signaling pathway-related genes, which were detected via reverse transcription-quantitative polymerase chain reaction, indicated markedly higher expression levels in groups $2,3,4,5$ and 6 compared with group 1. (B-D) Western blotting was used to detect the expression levels of p53/AMPK signaling pathway-related proteins. The expression levels of mTOR, p-mTOR, p53, AMPK $\alpha$ and sestrin were increased in the experimental groups compared with group 1 . Furthermore, when compared with group 5, p53, mTOR, p-mTOR, AMPK $\alpha$ and sestrin levels were significantly increased in groups 2, 3 and 4. Results for groups 2,3 and 4 suggest that GZYKF activates mTOR, p-mTOR, AMPK $\alpha$ and sestrin, and inhibits p53 in a dose-dependent manner. Data are presented as mean \pm standard error of the mean of three independent experiments. ${ }^{*} \mathrm{P}<0.05,{ }^{* * *} \mathrm{P}<0.01$, vs. group 5. p53, tumor suppressor p53; AMPK, adenosine monophosphate-activated protein kinase; TSC, tuberous sclerosis protein; mTOR, mechanistic target of rapamycin; $\mathrm{p}$, phosphorylated; TP, testosterone propionate; GZYKF, Gui Zhu Yi Kun formula; group 1, control; group 2, treated with TP and high-dose GZYKF-containing serum; group 3, treated with TP and medium-dose GZYKF-containing serum; group 4, treated with TP and low-dose GZYKF-containing serum; group 5, treated with TP and serum without GZYKF; group 6, treated with TP. 
increased in group 5 compared with the control group (both $\mathrm{P}<0.01)$. Furthermore, when compared with group 5, high-, medium- and low-dosages of GZYKF, were all able to significantly inhibit mRNA expression of Beclin-1 (all $\mathrm{P}<0.01$ ), whereas only high-dose GZYKF significantly inhibited the mRNA expression of LC3 ( $\mathrm{P}<0.05$; Fig. 3A). Western blot analysis indicated a significant increase in Beclin-1 and LC3 protein expression levels in groups 5 compared with the control group (both $\mathrm{P}<0.01$ ). GZYKF significantly decreased the protein expression levels of Beclin-1 (all $\mathrm{P}<0.01$ ), whereas LC3 was not significantly affected by GZYKF (Fig. 3B and C).

Effect of GZYKF on the p53/AMPK signaling pathway. RT-qPCR and western blotting were used to detect changes in molecules from the p53/AMPK signaling pathway following culture of GCs with GZYKF-containing serum. mTOR has a role in the inhibition of autophagy, whereas p53, AMPK, sestrin2, TSC1 and TSC2 promote autophagy (18). In the present study, mRNA expression levels of mTOR, p53, AMPK, sestrin2, TSC1 and TSC2 were significantly higher in group 5 than the control group (all $\mathrm{P}<0.05$ ). Furthermore, in groups 2 and 3 , significantly lower levels of p53 (both $\mathrm{P}<0.05$ ) and sestrin2 mRNA (both $\mathrm{P}<0.01$ ) as compared with group 5; however no significant difference was observed between groups 4 and 5 . Furthermore, no significant difference was observed among the expression levels of TSC1, TSC 2 and mTOR mRNA in groups 2, 3, 4 and 5. When compared with group 5, the level of AMPK mRNA was significantly higher in group $4(\mathrm{P}<0.05$; Fig. 4A). Results of western blot analysis demonstrated that mTOR, p-mTOR, p53, AMPK $\alpha$ and sestrin protein levels in group 5 were significantly decreased compared with those in the control group (all $\mathrm{P}<0.05$ ). Significantly higher levels of these proteins were exhibited in groups 2 (all $\mathrm{P}<0.05), 3$ (all $\mathrm{P}<0.01)$ and 4 (all $\mathrm{P}<0.01$ ) than in group 5. The results for groups 2, 3 and 4 further revealed a dose-dependent relationship between GZYKF and these proteins, as and increasing dose of GZYKF has a positive association with mTOR, p-mTOR, AMPK $\alpha$ and sestrin activation, whereas increasing inhibition of p53 was observed when the GZYKF dosage was increased (Fig. 4B-D).

\section{Discussion}

In the present study, data generated from the MTT assay for cell viability indicated that TP inhibits GC growth when applied at a concentration of $>10^{-6} \mathrm{~mol} / \mathrm{l}$. Prevalent and characteristic traits of PCOS are hyperandrogenemia and a reduced number of ovarian GCs (19). Therefore, TP may be used to induce a PCOS cell model in vitro. Various studies have reported autophagic cell death as one of the major mechanisms of cell death (20-22). The present findings suggest that TP activates autophagy, and that reduced ovarian GCs in PCOS may be associated with autophagy. The present study has also demonstrated that GZYKF may have the ability to decrease Beclin-1 protein, Beclin-1 mRNA and LC3 mRNA expression, which suggests that GZYKF potentially increases GC numbers by reducing autophagic cell death.

Finally, the results of the present study suggest that GZYKF mediates the p53/AMPK signaling pathway, which is closely associated with cell autophagy. There is a growing body of evidence supporting the ability of p53 to both upregulate and downregulate autophagic cell death (23-25). The results of the present study suggest that GZYKF may increase the expression levels of mTOR to inhibit autophagy, which may be associated with $\mathrm{p} 53$, AMPK and sestrin activation. p53, which is activated by GZYKF, further activates mTOR to inhibit autophagy in the cytoplasm. When p53 is activated by GZYKF in the nucleus, it also activates AMPK and sestrin, which acts as a feedback in mTOR inhibition, thereby activating autophagy. Therefore, on a cellular level, regulation of these proteins in the cytoplasm may be the primary mechanism associated with the therapeutic effects of GZYKF. A recent study by An et al (26) also reported that reductions in p53 and p-mTOR levels may promote autophagy. However, the disaccord between gene and protein expression of p53, AMPK and mTOR may suggest that the mechanism underlying GZYKF-regulated mediation of the p53/AMPK signaling pathway is associated with the transcription of mRNA and protein expression. Alternative hypotheses are that high-dose GZYKF is able to inhibit protein degradation, or that GZYKF may have multiple targeting functions.

In conclusion, the present study suggests that TP is able to induce a PCOS cell model in vitro, and that GZYKF mediates the p53/AMPK signaling pathway, and thereby inhibits GC autophagy, which may be the underlying mechanism of the therapeutic effects of GZYKF on PCOS.

\section{Acknowledgements}

This study was supported by a grant from the National Natural Science Foundation of China (grant no. 81202720).

\section{References}

1. Lang J (ed): Peking Union Medical College hospital: Polycystic ovary syndrome/Endocrine disorders of gynecology. In: Clinical practice guideline of gynecology. 1th edition. Ren Min Wei Sheng Chu Ban She, Beijing, pp258, 2012.

2. Hua L, Wu YN and Zhang JM: Clinical study of yishen jianpi yangxue tongli therapy in treating polycystic ovary syndrome. Zhongguo Zhong Xi Yi Jie He Za Zhi 23: 819-822, 2003 (In Chinese).

3. Canu N, Tufi R, Serafino AL, Amadoro G, Ciotti MT and Calissano P: Role of the autophagic-lysosomal system on low potassium-induced apoptosis in cultured cerebellar granule cells. J Neurochem 92: 1228-1242, 2005.

4. Nishida K, Kyoi S, Yamaguchi O, Sadoshima J and Otsu K: The role of autophagy in the heart. Cell Death Differ 16: 31-38, 2009.

5. Lum JJ, Bauer DE, Kong M, Harris MH, Li C, Lindsten T and Thompson CB: Growth factor regulation of autophagy and cell survival in the absence of apoptosis. Cell 120: 237-248, 2005.

6. Janku F, McConkey DJ, Hong DS and Kurzrock R: Autophagy as a target for anticancer therapy. Nat Rev Clin Oncol 8: 528-539, 2011.

7. Kabeya Y, Mizushima N, Ueno T, Yamamoto A, Kirisako T, Noda T, Kominami E, Ohsumi Y and Yoshimori T: LC3, a mammalian homologue of yeast Apg8p, is localized in autophagosome membranes after processing. EMBO J 19: 5720-5728, 2000.

8. von Hoven G, Kloft N, Neukirch C, Ebinger S, Bobkiewicz W, Weis S, Boller K, Janda KD and Husmann M: Modulation of translation and induction of autophagy by bacterial exoproducts. Med Microbiol Immunol: 201: 409-418, 2012.

9. Vousden KH and Ryan KM: P53 and metabolism. Nat Rev Cancer 9: 691-700, 2009.

10. Zhang XD, Qin ZH and Wang J: The role of p53 in cell metabolism. Acta Pharmacol Sin 31: 1208-1212, 2010.

11. Feng Z, Hu W, de Stanchina E, Teresky AK, Jin S, Lowe S and Levine AJ: The regulation of AMPK beta1, TSC2, and PTEN expression by p53: Stress, cell and tissue specificity, and the role of these gene products in modulating the IGF-1-AKT-mTOR pathways. Cancer Res 67: 3043-3053, 2007. 
12. Tong $\mathrm{Q}$, Jin $\mathrm{Z}$ and Shen XP: Investigate the autophagy rate of granulosa cell in polycystic ovary syndrome rat. Yi Nan Bing Za Zhi 10: 364-365, 2011 (In Chinese).

13. Campbell KL: Ovarian granulosa cells isolated with EGTA and hypertonic sucrose: Cellular integrity and function. Biol Reprod 21: 773-786, 1979.

14. Papadimitriou K, Kountourakis P, Kottorou AE, Antonacopoulou AG, Rolfo C, Peeters M and Kalofonos HP: Follicle-Stimulating Hormone Receptor (FSHR): A promising tool in oncology? Mol Diagn Ther 20: 523-530, 2016.

15. Ho ML, Hsieh YS, Chen JY, Chen KS, Chen JJ, Kuo WH, Lin SJ and Chen PN: Antimetastatic potentials of dioscorea nipponica on melanoma in vitro and in vivo. Evid Based Complement Alternat Med 2011: 507920, 2011.

16. Livak KJ and Schmittgen TD: Analysis of relative gene expression data using real-time quantitative PCR and the 2(-Delta Delta C(T)) Method. Methods 25: 402-408, 2001.

17. He C and Klionsky DJ: Regulation mechanisms and signaling pathways of autophagy. Annu Rev Genet 43: 67-93, 2009.

18. Budanov AV and Karin M: p53 target genes sestrin1 and sestrin2 connect genotoxic stress and mTOR signaling. Cell 134: 451-460, 2008.

19. Cataldo NA, Dumesic DA, Goldsmith PC and Jaffe RB: Immunolocalization of Fas and Fas ligand in ovaries of women with polycystic ovary syndrome: Relationship to apoptosis. Hum Reprod 15: 1889-1897, 2000.
20. Kroemer G and Levine B: Autophagic cell death: The story of a misnomer. Nat Rev Mol Cell Biol 9: 1004-1010, 2008.

21. Chen Y, Mcmillan-Ward E, Kong J, Israels SJ and Gibson SB: Oxidative stress induces autophagic cell death independent of apoptosis in transformed and cancer cells. Cell Death Differ 15: 171-182, 2008.

22. McPhee CK, Logan MA, Freeman MR and Baehrecke EH: Activation of autophagy during cell death requires the engulfment receptor Draper. Nature 465: 1093-1096, 2010.

23. Maiuri MC, Galluzzi L, Morselli E, Kepp O, Malik SA and Kroemer G: Autophagy regulation by p53. Curr Opin Cell Biol 22: 181-185, 2010.

24. Levine B and Abrams J: p53: The Janus of autophagy? Nat Cell Biol 10: 637-639, 2008.

25. Maiuri MC, Malik SA, Morselli E, Kepp O, Criollo A, Mouchel PL, Carnuccio R and Kroemer G: Stimulation of autophagy by the p53 target gene Sestrin2. Cell Cycle 8: 1571-1576, 2009

26. An HK, Kim KS, Lee JW, Park MH, Moon HI, Park SJ, Baik JS, Kim CH and Lee YC: Mimulone-Induced autophagy through p53-mediated AMPK/mTOR pathway increases caspase-mediated apoptotic cell death in a549 human lung cancer cells. PLos One 9: e114607, 2014. 